Vol 5 No 1 February 2020

E-ISSN: 2528-410X

ORIGINAL ARTICLE

\title{
Comparison of The Effectiveness Between Red Galangal Rhizome's (Alpinia Purpurata K.Schum) Extract And Ketoconazol 2\% To Inhibit Growth Of Dermatophyte Fungi In Vitro
}

\author{
Dewi Pangestuti ${ }^{1}$, Bilkes Harris ${ }^{2}$, Tuti Khairani Rahman $^{3}$ \\ ${ }^{1}$ Departement of Pharmacology and Therapy, Faculty of Medicine, Islamic University of North Sumatra, Medan, \\ Indonesia \\ ${ }^{2}$ Department of Dermatovenereology, Faculty of Medicine, Islamic University of North Sumatra, Medan, Indonesia \\ ${ }^{3}$ Faculty of Medicine, Islamic University of North Sumatra, Medan, Indonesia
}

Corresponding E-mail: pangestuti241073@gmail.com

\begin{abstract}
Red galangal rhizome (Alpinia purpurata k. Scum) has larger size and has more therapeutic properties. Red galangal has compounds that can inhibit fungal growth namely flavonoids and saponins which can interfere the function of the fungal cytoplasmic membrane, besides that they can cause leakage and aggregation of the outer cell membrane, which can inhibit the growth of dermatophytes.This study is a laboratory experimental study, using antifungal activity test with diffusion method using paper discs to see the comparison of the red galangal extract effectiviness and ketoconazole $2 \%$ on the growth of dermatophytic fungi Microsporum canis, Microsporum gypseum, and Trichophyton metagrophytes by measuring the inhibition zone around the fungal colonies. The concentrations of red galangal extract used were $10 \%, 20 \%, 30 \%, 40 \%$, and $50 \%$ and used $2 \%$ ketoconazole as control. The data was analyzed using the One Way Anova test. Result of this study shown that all consetration with out $10 \%$ of red galangal have inhibit zones of Microsporum canis, Microsporum gypseum, and Trichophyton metagrophytes but not better that ketoconazol $2 \%$ activities.
\end{abstract}

Keywords: Red galangal extract (Alpinia purpurata k. Scum), Ketoconazole 2\%, Dermatophytes

\section{INTRODUCTION}

Dermatophytes are a class of fungi that cause dermatophytosis. This group of fungi has keratin digesting properties. Dermatophytes belong to the fungi impecti class, which is divided into 3 genera, namely Microsporum, Trichophyton, and Epidermophyton. Dermatophytosis is also called "tinea" infection which is further grouped based on the location of the 
infection, namely: Tinea capitis, Tinea corporis, Tinea cruris, Tinea manus et pedis, Tinea unguium, Tinea barbae and Tinea imbrikata. ${ }^{1}$

including white rhizomes (white galangal) and red rhizomes (red galangal). Red galangal rhizome has a larger size and more therapeutic efficacy. ${ }^{2}$ Red Galangal (Alpinia purpurata $k$. Schum) has been studied in various studies and it has been proven that this plant has various biological effects such as anti-inflammatory, antioxidant, antifungal, antiviral, antibacterial, and anticancer activity. ${ }^{3}$ The content of galangal contents include $0.5-1.5 \%$ volatile oil containing 1.8-sinerol component 5.6\%, eugenol, methylcinamic $2.6 \%$. The biting heat and warmth comes from a mixture of volatile compounds namely diarilheptanoid (galangol), and there are also gingerols, acetoxicrichol acetate, acetyleugenol acetate, and karyophilenol-1. In addition to essential oils, there are also flavonoids derived from quercetin, kaemferida, 7-hydroxy-3,5dimethoxy flavone, galangin $(3,5,7$, trihydroxyplavone), alpinine, isoramnetin, kaemferol, kaemferol-7-methyleter, kaemferol-4 -metileter, quercetin, and quercetin-3-methyleter. ${ }^{4}$ Some flavonoids in galangal rhizome have been identified such as kaemperol, kaemferide, galangin and alpinin. The mechanism of action of flavonoids in inhibiting fungal growth is by causing disruption of fungal cell membrane permeability. Hydroxyl groups found in flavonoid compounds cause changes in organic components and nutrient transport which will eventually result in fungal cells becoming lysis. ${ }^{5}$ Based on research conducted by Haraguchi, antifungal activity

Buletin Farmatera

Fakultas Kedokteran (FK)

Universitas Muhammadiyah Sumatera Utara (UMSU)

http://jurnal.umsu.ac.id/index.php/buletin_farmatera of galangal by diterpene compounds is associated with changes in fungal lipid membrane permeability. ${ }^{6}$ Meanwhile, according to research conducted by Brian $\mathrm{J}$ Kopper regarding the effect of diterpene on fungi, it has been proven that it is efficacious as an antifungal by reducing fungal cell division and fungal mycelial growth. ${ }^{7}$ Based on research conducted by Silvina, galangal rhizome extract $10 \%$ more effective when compared with $2 \%$ ketoconazole in inhibiting the growth of Candida albicans in candidiasis vaginalis. ${ }^{8}$

\section{METHODS}

This research is a type of laboratory experimental research using post test only control group design to see the comparison of the effectiveness test of red galangal rhizome extract (Alpinia purpurata k.schum) with a concentration of $10 \%, 20 \%, 30 \%$, $40 \%, 50 \%$, and ketoconazole $2 \%$ in inhibiting the growth of dermatophyte fungi. Red galangal extract in this study was obtained with a weight of 160 grams in the form of a thick extract.

This research was conducted at the Microbiology and Phytochemistry Laboratory of the Faculty of Pharmacy, University of North Sumatra. The sample of this study was dermatophyte fungi taken from the Microbiology Laboratory of the Faculty of Pharmacy, University of North Sumatra which consisted of Microsporum canis, Microsporum gypseum, and Trichophyton metagrophytes.

The extraction process is carried out using the maceration method. Antifungal testing was carried out by the diffusion method using disc paper soaked in red 
galangal extract that had been made in each dilution concentration with DMSO solution, i.e. concentrations of $10 \%, 20 \%, 30 \%, 40 \%$, and $2 \%$ ketoconazole implanted. into the fungus Microsporum canis, Microsporum gypseum, and Trichophyton metagrophytes on Sabouraud Dextrose Agar media.

Analysis of the inhibition zone diameter data was performed using the Shapiro Wilk test and then continued with the One Way Anova test.

\section{RESULTS}

Galangal has several known varieties, Phytochemical screening results of red galangal ethanol extract in table 1 show the presence of flavanoids, glycosides, saponins and triterpenoids.

The results of inhibition zones of red galangal extract with various concentrations in table 2 show that for T. Metagrophytes, inhibitory zones were seen at all concentrations ranging from $10 \%$ to $50 \%$, while the shows of $M$. canis and $M$. gypseum inhibitory zones were seen starting at concentrations of $20 \%$. Ketoconazole as a positive control showed inhibition zones in each repetition (table 3 ). Comparison of mean diameter of inhibition zone of red galangal rhizome extract based on concentration compared to ketoconazole showed a significant difference in all fungal species (table 4).

Table 1. Phytochemical screening results of red galangal ethanol extract

\begin{tabular}{llc}
\hline No. & \multicolumn{1}{c}{ Screening } & Results \\
\hline 1. & Alkaloids & - \\
2. & Flavonoida & + \\
3. & Glycosides & + \\
4. & Saponin & + \\
5. & Tannin & - \\
6. & Triterpenoida & +
\end{tabular}

Notes:

$(+)=$ contains a class of compounds; $(-)=$ does not contain compounds

Table 2. Results of Inhibition Zones of Red Galangal Extract with Various Concentrations on Fungal Growth Microsporum canis, Microsporum gypseum, and Trichophyton metagrophytes.

\begin{tabular}{llccccc}
\hline No & Dermatophytes fungi & \multicolumn{5}{c}{$\begin{array}{c}\text { Inhibition Zone Diameter of Each Concentration } \\
\text { Red Galangal Extract (mm) }\end{array}$} \\
\cline { 3 - 7 } & & $\mathbf{5 0 \%}$ & $\mathbf{4 0 \%}$ & $\mathbf{3 0 \%}$ & $\mathbf{2 0} \%$ & $\mathbf{1 0 \%}$ \\
\hline 1. & M. canis (I) & 8,4 & 8,0 & 7,4 & 6,9 & - \\
& M. canis (II) & 8,8 & 8,4 & 7,0 & 6,8 & - \\
& M. canis (III) & 8,3 & 7,8 & 7,1 & 6,6 & - \\
\hline & Mean: & 8,5 & 8,06 & 7,16 & 6,76 & - \\
\hline 2. & M. gypseum (I) & 9,5 & 8,3 & 7,4 & 7,0 & - \\
& M. gypseum (II) & 9,0 & 8,2 & 7,6 & 6,8 & - \\
& M. gypseum (III) & 9,4 & 8,4 & 7,8 & 6,9 & - \\
\hline & Mean: & 9,3 & 8,3 & 7,6 & 6.9 & 6,9 \\
\hline 3. & T. metagrophytes (I) & 9,9 & 8,8 & 8,4 & 7,6 & 7,0 \\
& T. metagrophytes (II) & 10.0 & 8,9 & 8,6 & 8,0 & 6,9 \\
& T. metagrophytes (III) & 9,7 & 9,0 & 7,9 & 7,4 & \\
\hline & Mean: & 9,86 & 8,9 & 8,3 & 7,66 & \\
\hline
\end{tabular}

Notes:

(I)= Repetition 1 ; (II) = Repetition 2; (III) = Repetition 3 
Vol 5 No 1 February 2020

E-ISSN: 2528-410X

Table 3. Results of Ketoconazole Tablets $2 \%$ Inhibition Zones Against Fungal Growth Microsporum canis, Microsporum gypseum, dan Trichophyton metagrophytes.

\begin{tabular}{llcccc}
\hline \multirow{2}{*}{ No. } & Dermatophytes fungi & \multicolumn{3}{c}{ Ketoconazole Tablet 2\% Inhibition Zone } & Mean \\
\cline { 3 - 5 } & & \multicolumn{3}{c}{ Diameter (mm) } & \\
\cline { 3 - 5 } & & 27,9 & (II) & (III) & \\
\hline 1. & M. canis & 28,4 & 28,9 & 28,4 \\
2. & M. gypseum & 29,3 & 30,0 & 29,7 & 29,67 \\
3. & T. metagrophytes & 31,6 & 30,9 & 31,2 & 31,23 \\
\hline
\end{tabular}

Notes:

(I) =: Repetition 1; (II) = Repetition 2 ; (III) = Repetition 3

Table 4. Difference in Average Diameter of Inhibitory Zone of Red Galangal Rhizome Extract Based on Concentration and Ketoconazole $2 \%$ in Each Fungal.

\begin{tabular}{|c|c|c|c|c|c|}
\hline \multirow[t]{2}{*}{ Fungal } & \multirow[t]{2}{*}{ Treatment } & \multicolumn{4}{|c|}{ Inhibitory Zone Diameter (mm) } \\
\hline & & Mean & SD & Sig. & $p$-value \\
\hline M. canis & $\begin{array}{l}\text { Konsentrasi 50\% } \\
\text { Konsentrasi } 40 \% \\
\text { Konsentrasi 30\% } \\
\text { Konsentrasi 20\% } \\
\text { Konsentrasi 10\% } \\
\text { Ketokonazol 2\% } \\
\text { Blank (DMSO) }\end{array}$ & $\begin{array}{l}8,5000 \\
8,0667 \\
7,1667 \\
6,7667 \\
0 \\
28,4000 \\
0\end{array}$ & $\begin{array}{l} \pm 0,26458 \\
\pm 0,30551 \\
\pm 0,20817 \\
\pm 0,15275 \\
0 \\
\pm 0,50000 \\
0\end{array}$ & $\begin{array}{l}0,365^{a} \\
0,637^{a} \\
0,463^{a} \\
0,637^{a} \\
0 \\
1,000^{a} \\
0\end{array}$ & $0,000^{*}$ \\
\hline M. gypseum & $\begin{array}{l}\text { Konsentrasi 50\% } \\
\text { Konsentrasi } 40 \% \\
\text { Konsentrasi 30\% } \\
\text { Konsentrasi 20\% } \\
\text { Konsentrasi 10\% } \\
\text { Ketokonazol 2\% } \\
\text { Blank (DMSO) }\end{array}$ & $\begin{array}{l}9,3000 \\
8,3000 \\
7,6000 \\
6,9000 \\
0 \\
29,6777 \\
0\end{array}$ & $\begin{array}{l} \pm 0,26458 \\
\pm 0,10000 \\
\pm 0,20000 \\
\pm 0,10000 \\
0 \\
\pm 0,40000 \\
0\end{array}$ & $\begin{array}{l}0,363^{a} \\
1,000^{a} \\
1,000^{a} \\
1,000^{a} \\
0 \\
0,956^{a} \\
0\end{array}$ & $0,000^{*}$ \\
\hline T. metagrophytes & $\begin{array}{l}\text { Konsentrasi 50\% } \\
\text { Konsentrasi } 40 \% \\
\text { Konsentrasi 30\% } \\
\text { Konsentrasi 20\% } \\
\text { Konsentrasi 10\% } \\
\text { Ketokonazol 2\% } \\
\text { Blank (DMSO) }\end{array}$ & $\begin{array}{l}9,8667 \\
8,9000 \\
8,3000 \\
7,6667 \\
6,9000 \\
31,2333 \\
0\end{array}$ & $\begin{array}{l} \pm 0,15275 \\
\pm 0,10000 \\
\pm 0,36056 \\
\pm 0,30551 \\
\pm 0,10000 \\
\pm 0,3511 \\
0\end{array}$ & $\begin{array}{l}0,637^{a} \\
1,000^{a} \\
0,537^{a} \\
0,637^{a} \\
1,000^{a} \\
0,843^{a} \\
0\end{array}$ & $0,000^{*}$ \\
\hline
\end{tabular}

Notes:

$a=$ Shapiro Wilk test: $p>0.05$ : normally distributed data; ${ }^{*}=$ One way Anova test: $p<0.05$ : significant differences

\section{DISCUSSIONS}

In this study the inhibition zone diameter of red galangal extract with a concentration of $10 \%, 20 \%, 30 \%, 40 \%$, and $50 \%$ were tested on fungal Microsporum canis, Microsporum gypseum, and Trichophyton metagrophytes, indicates antifungal activity. Antifungal

Buletin Farmatera

Fakultas Kedokteran (FK)

Universitas Muhammadiyah Sumatera Utara (UMSU)

http://jurnal.umsu.ac.id/index.php/buletin_farmatera activity of red galangal extract is classified as moderate. This is in accordance with the opinion of Greenwood, which states that if the diameter of the inhibitory power is 5-10 $\mathrm{mm}$, the inhibitory activity is classified as moderate. ${ }^{9}$ 
E-ISSN: 2528-410X

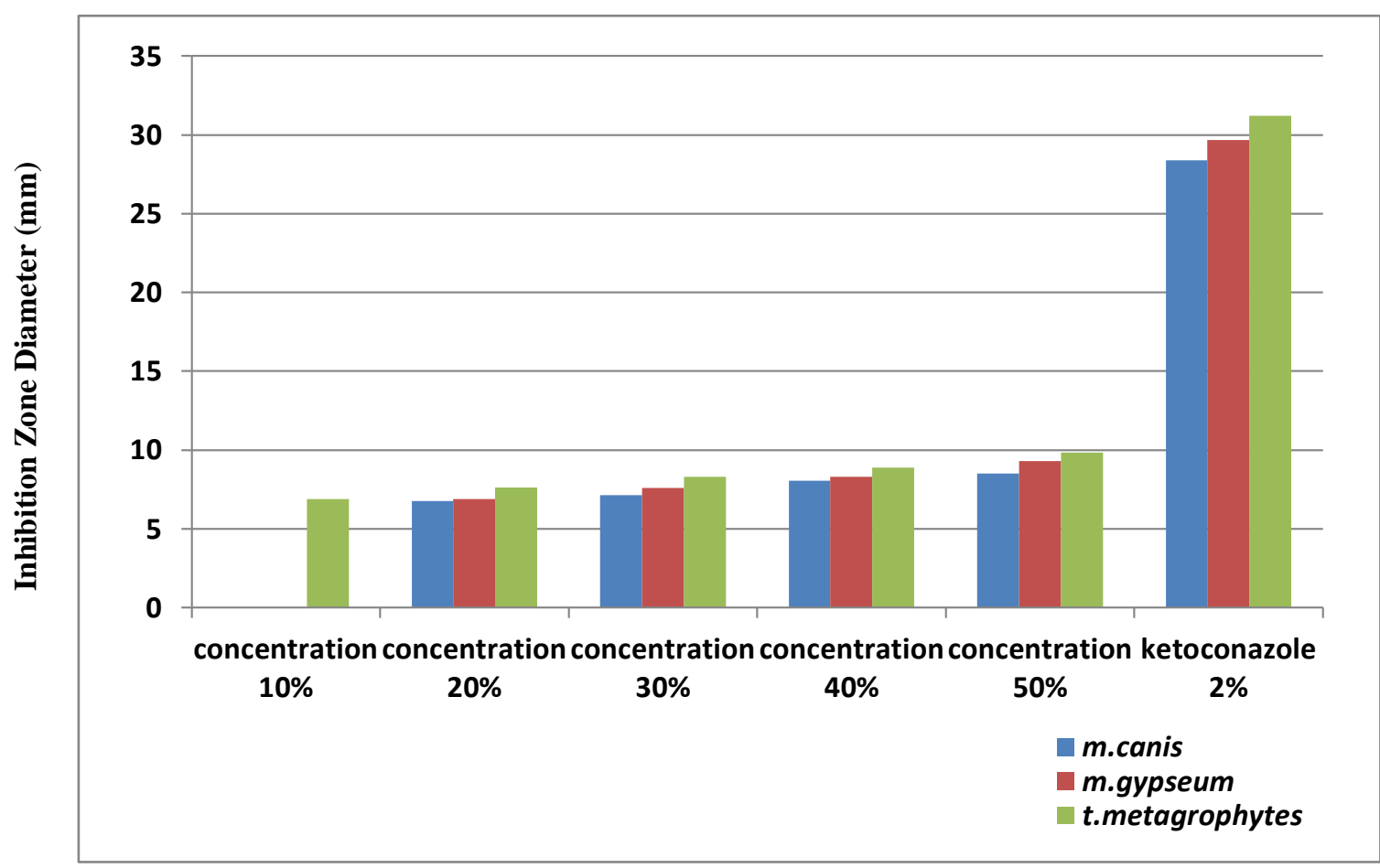

Figure 1. Distribution of the Average Inhibitory Zone Diameter of Red Galangal Rhizome Extract Based on 2\% Concentration and Ketoconazole Against Fungus Microsporum canis, Microsporum gypseum, and Trichophyton metagrophytes

Based on the phytochemical screening results, red galangal extract contains flavonoids, glycosides, saponins, and triterpenoids. Antifungal contents found in red galangal extract include flavonoids and saponins. Flavonoids are anti-inflammatory, antimicrobial, analgesic and anti-oxidant compounds. Flavonoids are the largest group of phenol compounds, phenol compounds have the property of effectively inhibiting the growth of viruses, bacteria, and fungi. Flavonoids cause damage to the permeability of fungal cell walls. The antiinflammatory mechanism occurs through its inhibitory effect on the arachidonic acid metabolism pathway, the formation of prostaglandins, the release of histamine in inflammation. Flavonoids contain phenol compounds. Phenol is a type of acidic alcohol so it is also called carbolic acid.
Phenols have the ability to denaturate proteins and damage fungal cell walls. ${ }^{10}$

Saponin compounds can disrupt the stability of cell membranes in fungi that cause damage to cell membranes and cause the release of various important components of the fungal cells, namely proteins, nucleic acids and nucleotides. ${ }^{11}$

Based on the measurement results show that the fungus Trichophyton metagrophytes has the largest average diameter of the inhibitory zone. This is because the fungus Trichophyton metagrophytes has an anthropophilic living habitat that is transmission from human to human. Anthropophilic species cause relatively mild and chronic infections in humans, produce little conidia in culture, and can be eradicated. The Trichophyton metagrophytes colony has a granular cotton form showing 
many groups of round micronidia shaped like grapes in terminal 20 branches. Tricophyton dermatophytes with fine-walled microscopic morphology have adapted to humans as hosts, and will cause a mild to non-inflammatory response. ${ }^{12}$

Based on the measurement results show that the Microsporum gypseum fungal has the second largest inhibitory zone diameter after Trichophyton metagrophytes. This is because the Microsporum gypseum fungal has a goefilik living habitat that is transmission from soil to humans. As a species that evolved from soil habitats to human hosts, the Microsporum gypseum fungus loses the ability to produce asexual conidia and reproduce sexually to produce spores. Microsporum gypseum forms a light brown colony like powder and many fourto-six-celled thick-walled macronidia. ${ }^{13}$

Based on the measurement results show that the Microsporum canis fungal has the smallest inhibitory zone diameter. This is because the Microsporum canis fungus has a zoophilic living habitat that is transmission from animals to humans. Microsporum canis form colonies with white surfaces such as cotton, thick-walled macronsides, 8 to 15 cells, and often have curved and hooked ends. Zoophilic species infections usually produce severe inflammation. ${ }^{13}$

In a study conducted by Silvina on the Comparative Test of the Effectiveness of Galangal Rhizome Extract (Alpinia Galanga) $10 \%$ with Ketoconazole $2 \%$ In Vitro Against the Growth of Candida Albicans in Vaginal Candidiasis. It was found that Candida albicans grows more on Sabouraud Dextrose Agar media containing $2 \%$ ketoconazole compared to Sabouraud Dextrose agar media containing $10 \%$ galangal rhizome extract so that it can be concluded that there is a difference in effectiveness between $2 \%$ ketoconazole and $10 \%$ galangal rhizome extract in vitro. ${ }^{8}$

From this research it can be seen that the higher the concentration of red galangal extract, the higher the diameter of the inhibition zone formed. The same thing was also found in research on Comparison of the Effectiveness of Red Galangal (Alpinia purpurata $k$ schum) and White Galangal (Alpinia galanga) on the growth of Candida Albicans Fungal in vitro. The size of the inhibition zone is influenced by the concentration of the extract given, increasing the concentration of the extract causes an increase in the content of the active ingredient that functions as an antifungal so that its ability to inhibit the growth of a fungus is also greater. Unequal increase and decrease in inhibition zone can be caused by the solubility of the active substance in the extract and the difference in the diffusion rate of the agar media. ${ }^{14}$

\section{CONCLUSIONS}

Measurement of inhibition zone diameter of red galangal extract of various concentrations in Trichophyton metagrophytes fungi had the largest average diameter of inhibitory zone. Measurement of the diameter of the inhibition zone of red galangal extract of various concentrations in Microsporum canis fungi has an average diameter of the smallest inhibitory zone. Comparison of the effectiveness of red galangal rhizome extract and ketoconazole $2 \%$ in dermatophyte fungi is that the antifungal activity of $2 \%$ ketoconazole is more effective than the red galangal rhizome extract, although the antifungal activity of red galangal extract is classified as moderate. The higher the concentration of red galangal extract, the wider the inhibition zone dimension. 


\section{REFERENCES}

1. Djuanda, A. et al. Ilmu Penyakit Kulit dan Kelamin. Edisi 7. Jakarta: Badan Penerbit Fakultas Kedokteran Universitas Indonesia. 2015.

2. Latief, A. Obat Tradisional. Jakarta: Penerbit Buku Kedokteran EGC. 2012.

3. Prasetyo, K.R.D. Uji Beda Daya Hambat Ekstrak Rimpang Lengkuas Merah (Alpinia purpurata K.Schum) dengan Ekstrak Rimpang Lengkuas Putih (Alpinia galanga W.) Terhadap Candida albicans. Jember: Fakultas Kedokteran Gigi Universitas Jember. 2016.

4. Wiryowidagdo, S. Kimia dan Farmakologi Bahan Alam. Edisi 2. Jakarta: Penerbit Buku Kedokteran EGC. 2008.

5. Abad, G. B., et al. Characterization and Metabolic Diversity of Flavonoids in Citrus Species. US National Library of Medicine National Institute of Health. 2017.

6. Haraguchi H, Oike S, Muroi H, Kubo I.Mode of antibacterial action of totarol, a diterpene from podocarpus nagi.Planta Med.1996; 62(2): 122-25

7. Widyawati. Uji Banding Efektivitas Laos (Alpinia galanga) 2\% Dengan Ketokonazol $2 \% \quad$ Terhadap Pertumbuhan Malassezia furfur Pada Pityriasis versikolor. Semarang: Fakultas Kedokteran Universitas Diponegoro. 2006.

Buletin Farmatera

Fakultas Kedokteran (FK)

Universitas Muhammadiyah Sumatera Utara (UMSU)

http://jurnal.umsu.ac.id/index.php/buletin_farmatera
8. Silvina, Uji Banding Efektivitas Ekstrak Rimpang Lengkuas (Alpinia galanga) 10\% Dengan Ketokonazol 2\% Terhadap Pertumbuhan Candida Albicans Pada Kandidiasis Vaginalis. Semarang: Fakultas Kedokteran Universitas Diponegoro. 2006.

9. Greenwood. Antibiotic Susceptibility (Sensitivity) Test, Antimicrobial and Chemotherapy. Mc Graw Hill Company: USA. 1995.

10. Kurniawan, D. Uji Aktivitas Antijamur Ekstrak Etanol Daun Kelor (Moringa Oleifera Lamk.) Terhadap Candida Albicans Secara In Vitro. Pontianak: Fakultas Kedokteran Universitas Tanjungpura. 2015

11. Alfiah, R, R., Khotimah, S., dan Turnip, M. Efetivitas Ekstrak Metanol Daun Sembung Rambat (Mikania micrantha Kuth) Terhadap Pertumbuhan Jamur Candida albicans. Pontianak: Jurnal Protobion. 2015.

12. Fitzpatrick's., Dermatology in General Medicine. New york: The McGraw-Hill Companies. 2012

13. Jawetz, M. et al. 2014. Mikrobiologi Kedokteran. Edisi 25. Jakarta: Penerbit Buku Kedokteran. EGC. 2014

14. Naldi, Y., dan Aisah, I.S. Perbandingan Efektivitas Lengkuas Merah (Alpinia Purpurata K Schum) dan Lengkuas Putih (Alpinia Galanga) Terhadap Pertumbuhan Jamur Candida Albicans Secara In Vitro. Cirebon: Fakultas Kedokteran, Universitas Swadaya Gunung Jati. 2014. 